\title{
A Study of Analysis and Evaluate Issues and Challenges in Sport Events
}

\author{
Weerakoon Ranjan \\ Lecturer, Department of Sport Science and Physical Education, University of Kelaniya, Sri Lanka
}

\begin{abstract}
The primary aim of this study is to address the importance of issues and challenges in relation to local community and sponsors of international sport events. This report is built on and primary and secondary data. The analysis concentrate on the social issues and sponsorship challenges, due to the fact that the environment pollution, increase crime, traffic and parking issues, loosing sponsorship, and other issues in relation to sport event. The first part of this report will give a brief outline of analysis on social issues and challenges arising due to sport event this report will examine few different issues caused by the economic impact of sport's event for the society and other social and environmental issues and carefully analysing practical solutions provided by other sport event and organisations. The next part will be discovered the sponsor issues and sponsorship challenges, sport organisers has faced in their sport event as well as more concern about the ambush marketing issue in sport events which is critical issue for sport event sponsorship, and exploring solutions taken by world sport organisation and event organisers.

Finally, this report concerned all the issues and challengers, providing recommendation for world sport organisations to minimise and reduce negative impact of sport event as well as provide suggestion for improve positive impact of sport event for the better world.
\end{abstract}

Keywords: Sport Events, Social impacts, Sponsorship, economic, environmental issues

\section{Introduction}

This study was written to provide advice to international sport federations (ISFs) in Lausanne, Switzerland, about current issues and challenges in international sport event management. In particular, the study was commissioned to address:

1. Issues around the impact of international sport events on the local community;

2. Current challenges for international sport events in relation to sponsorship.

ISFs are the rights owners to many major international sport events (such as world championships, and world cup events), and therefore it is imperative that they should be aware of and dealing with any significant problems around current sport event management. This report aims to explore the key issues within these two areas (local community and sponsorship), identify examples of good practice from other events, and provide recommendations for improving the delivery of major sport events.

\section{Methodology}

The report was written using both secondary and primary data sources:

Secondary data was derived from academic sources, including key texts and research journal articles related to the topic of sport event management. These sources are identified fully in the reference list. The academic resources have been focused sport events' social impact and sport event sponsorship issues and challenges' literature.

Secondary data was also consulted in the form of reports from major sport events, exploration of other ISF websites, and other world organisation such as UN, WWF, and IOC.

Primary data was collected on a fieldtrip to Lausanne in March 2016, involving visits to several ISFs. During these visits, the issues of local community impact, and event sponsorship were explored with senior figures within the Federations. There are collected data regarding practical issues of sport events, when they are faced going to organise sport events which has provided in-depth detail and understand of selected topic.

\section{Local Community Issues and Challenges}

\section{Findings}

Sport mega events create advantage and disadvantage in many ways such as sociocultural, economic, and ecological. All these impacts are affected directly and indirectly to local residents (Witt, 1988;Kim, Gursoy and Lee, 2006). These event impacts are influence to host community before and long after the event is finished (Ritchie \& Aitken, 1985; Roche, 1994; Ritchie et al., 2009). The positive social impacts includes increased community pride, quality of life, strengthen of cultural values and tradition, opportunities for education, emotional experience and could be help to build national identity (Hall, 1989; Waitt, 2003; Kim \& Petrick, 
2005; Kim et al., 2006; Ritchie et al., 2009). Conversely, hosting a mega sport event has created negative impacts for the local community such as increase in price of goods, service and property providing an economic and social burden (Brown, 2000).

\section{Sport event's Economic Impact for Society}

In late twentieth century, sport event has used as an approach for economically develop for host city which are used for urban regeneration, infrastructure development, enhance local business opportunities and increase public welfare (Preuss, 2007). In particular, mega sport events such as the Olympic game, World cup, Commonwealth game and world championships have been used cities as a development strategy (Magdalinski and Nauright, 2004;Preuss et al., 2007;Misener and Mason, 2006 ). On the other hand, the work of Deccio and Baloglu (2002) shows that mega event has cause for price inflation and increase local tax due to construct facilities for host event that is burden for local financial as well as mismanagement of public funds by organisers cause to negative economic impacts for the host community. As an example after the 1976 Montreal Olympic game, this may cause to increase tax payment over time and it's took several decade to repay hosting the event due to mismanagement of founds (Hillier, 1998). However, ASOIF is providing their consultant and support to International Olympic committee to select the host city for Olympic Games which consider Game budget, long term infrastructure, investment budget and its benefits for local community as well as they provide expert Knowledge for the particular Olympic Organising committee and also IOC provide the financial back for the host organising county to held Olympic game (ASOIF, 2016; IOC, 2016).

\section{Other Social Issues and Challenges Arising due to Sport Event}

The evident seems to indicate that the success is not only expectation of mega sport event, Olympic heavily depends on the goodwill of the local community (Kim et al., 2006). However, while conducting a sport mega event its make plus and mines points on host community. Tosun (2002), Mihalk and cummings (1995) and many other researchers have drawn attention to the fact that common social issues and challengers in international sport event, there are arising common social and cultural problems due to mega sport events such as negative influence on traditional family values, cultural commercialization and conflict between the host community and tourist due to different standard of living conditions, welfare and purchasing power. In addition, turning to Mihalik and Cummings (1995) and Fredline, (2004) one find that traffic conjunction and parking problem have been occurred by the construction of facilities to host mega event and during the actual events, thus criminal offense have been increased by the entrance of people and migrant workers which may further affect skill shortages, furthermore, Fredline (2004) makes clear that community people are sometime against sport event because over accesses people and loss their recreation amenity, as an example local people have protested again Bondi beach volleyball event in Sydney 2000 Olympic game consequently lost their recreational amenity (Waitt, 2003). In present, terrorist attack major possible threat of international sport events, if there is happened unexpected bomb attack in location it spoil whole game and image of city and county (Preuss, 2007). however, IOC and ASOIF have provided a guild line and consultant to host organizing committee for avoiding and mitigating social burden in every possible angles, but if they consider basic guild lines (Social, Cultural and economic) for awarding host city of Olympic Game, they cannot avoid unexpected circumstances such as economic rescission and terrorist attack, IOC and ASOIF have reasonable doubt about the RIO 2016 Olympic Game due to Brazil economic rescission (IOC, 2016; ASOIF, 2016). INEI (2014) reported that over 47.9\% of 15-29 age group people engage to crime in Peru and also the 70, 0000 reported crime in London between years 2013-14 (Metropolitan police, 2015). Considering all these Social matters Sport Accords has selected Lima to hosting the 2017 world combat game and they will introduce 'Social, education, and cultural program for the spectators as solution of increase crime (Sport Accord, 2015). The planning of world beach game in 2014, there are required two stadiums venues, one stadium venues constructed by one side open out to the sea which constructed by temporary only for the game that is good example for the solution of lost general public recreation amenity(Sport Accord, 2015). Beijing Olympic 2008 has main issue that the transport and traffic control in Beijing city during the game, however organising committee has implemented new and modern transportation plan, so they were developed their airport as a multi-functional hub and also used train as the main transportation method and increased public transport usage by $60 \%$ and increased police control areas $10 \%$ to $15 \%$, thus divided road lane as a priority lane for Olympic athletes and official transport and kept a high way speed limed less than $60 \mathrm{mph}$, using these transport strategies Beijing has overcome the transport challenge (Bovy, 2009)

\section{Environment}

Around 2 million tons of human waste is disposed into the nearby water ways and $70 \%$ of industrial waste is removed into nearby rivers from developed countries (UNEP, 2009; UN water, 2014). Fresh water of the world is $2.5 \%$ which is seem to lack in near future due to the population growth. These entire problems are 
social problem in general and sport in particular. The evidence seems to indicate that one of problem is crowed in sport event which produce considerable amount of west (Jenikins, 2012; Coalter and Taylor, 2008). Considering this matter following Zero west policy set three colour bin system by the LOCOG (2012) which is helped to do their task properly for recycling team. This system was accepted by the WRAP (2012) and transfers that knowledge to future events. On other hand, event has created $\mathrm{CO} 2$ regarding to transport and energy. As strategies for solution this matter used planting tree and saving energy by Beijing Olympic game organizing committee. These activities are helped to enhance people environmental awareness (UNEP, 2009). Furthermore, Sydney, Beijing, and London Olympic game have implemented strategies for greener event such as use of rain water to flush toilets, power different shortage equipment with solar energy, compostable cutlery and among others (SOCOG, 2003; UNEP, 2009; Great London Authority, 2012).

Furthermore, Jenkins (2012) has drawn attention to the fact that supply chain has the main problem of above outline matters, therefore minimize this problem researcher recommend use resources surround areas when possible such as haring local people as much as possible.

\section{Sponsorship Issues and Challenges}

The sponsorship could be define as an agreement between two parties which provide some kind of resources such as money, people and equipment for the event or organisation that has benefit for the broth side (Lee et al., 1997). Sleight (1989) has drawn attention to fact that sponsorship is a business relationship which provides fund resource or services to events therefore events or organisation offer in return some right or commercial advantage.

In present, event sponsorship is one of rapidly growing sector of marketing communication (Meenaghan, 1999). However nowadays event sponsorship has become an important issue in sport marketing and critical concern for event management (McDaniel, 1999). Basically, sport popularity is a main point for increase investment in particular sport event, however many of sport less fortunate to commercially success and not great public support therefore it does not attractive broadcasters, advertisers and sponsors (Brown, 2000). Some other sports has invested sum of money but it does commercially unsuccessful. Even athletics is main game in Olympic sports, does not attractive more spectators outside the Olympic. This is similar to hockey, volleyball, handball, shooting, swimming, wrestling, judo, fencing, and weightlifting, rowing, canoeing and skating as well. These sports are highly depending on Olympic funds. Dutch rowing club is a good example for low sponsorship attraction.

Another critical problem highlighted by the researcher is that ambush marketing in event which has been significant problem the Olympic landscape over recent Olympiads (Payne, 1998). In addition, Government rules and regulations affect to the sport event sponsorship, specially, in alcohol sponsors cannot sponsors to the sport event in some countries that is prohibited by the government laws. The New Zealand government prohibited alcohol sponsorship in sport event because it is influence to drinking culture (Cody and Jackson, 2014; Crompton, 1993).

In 1984 Los Angeles Olympic Kodak did ambush marketing against the Fujifilm, Fujifilm did ambush marketing against Kodak in 1988 Seoul Olympic, Nike engaged in ambush marketing in 19996 Olympic Games against Reebok and Qantas Airline did ambush marketing in 2000 Sydney Olympic game. Considering all the past experiences IOC introduced 'anti ambush kit' for protect official sponsors' commercial rights during 2006 Turin winter Olympic game. This was a new campaign by IOC to raise the awareness of the contribution of Olympic sponsors and negative impact of ambush marketing as well as IOC put pressure on host cities to prevent ambush marketing by introducing new law in Olympic charter (Ellenn, 2010). After awarded to Olympic game for London, Government was introduced new legislation to prevent and control the ambush marketing during the period of the game which is called London Olympic game and Paralympic game act (Ellenn, 2010). This is a good practical solution for event ambush marketing which is enhanced sponsors trust about their benefits and influence make more sponsoring in sport event. Sport popularity is one of problems in sport event sponsorship; however world rowing got the reliable solution for that get partnership with WWF because both organizations have same aims and values for clean water (WWF, 2015) and also FISA have partnership with BMW for clean water and green events (FISA,2013).

\section{Recommendations}

After analysing all the information which is presented in previous, the recommendation provide as follows; Social Issues and Challenges

Increase crime, environmental pollution and may other social problem arising during an event which is significant problem in society, the power of sport has been proved several time (Fujiwara, kudrna and Dolan, 2014, sport England, 2015) and also sport stars are seen as a role model in society(Lyle, 2006). Therefore event organisers could be able to use athletes from different sport to participate and promote different social values and environmental sustainable actions not only in multi-sport game that can be use individual sport events. This 
impact can be spread out the world because International federation directly connect with the national sport organisation. And also sport event organisers should be concern about the cultural and education programs for fans along with the events which could be help to improve social values, norms and mutual understand between different groups of people.

The transport and traffic control are one of major challenges in sport mega event. Therefore event organisers wise to promote and use their most efficient transport mode during the event. The past Olympic Games show that highlight the transport development, mostly use in rail public transport. The event organisers should be innovating with temporary transport and traffic schemes should be providing maximum priority to mass public transportation and also transport development should not be the 'white elephant', it should be the sustainable and long lasting legacy. The Beijing Olympic game's organisers has given permission to use bicycle/bike and public transport within the Olympic village and provide 24 hour free parking facilities for fans near the Olympic village (Bovy, 2010). This one of practical solutions for transport and traffic problem.

\section{Sponsorship Issues and Challenges}

Sponsors are one of key stakeholders in the responsible development of an event (Seguin and Bodet, 2015). Therefore event organisers should be attracted sponsors represent their values. The 2012 Olympic Game waste management pregame is one of good program for sponsors to play an important role which is a great opportunity for funding event at the same time as helping them move forwards greater opportunity like FISA and BMW for clean water (FISA, 2013) or NBA green week presented by sprint (NBA, 2015) are proof of the power of this new perspectives in the sponsorship area, offering new prism to look through when planning the event.

The good sponsorship not just the money, it has considerable values shearing both sides. The long term relationship may benefits more value than the direct income initially received. And also sponsorship relationship needs significant investment and commitment from both sides, therefore sport organization should be provide system, policies, legal background, structure and service to ensure the sponsor receives good values (Sport New Zealand, 2012).

\section{References}

[1]. ASOIF (2016) Olympic Game. Available at: http://www.asoif.com/olympic-games(Accessed: 20/04/2016).

[2]. Brown, G., (2000). Emerging issues in Olympic sponsorship: Implications for host cities. Sport Management Review, 3(1), pp.7192.

[3]. Coalter, f. and Taylor, j. (2008). Large scale Sport Events: A case study of FA cup final. Availble at: https://dspace.stir.ac.uk/bitstream/1893/1942/1/Large\%20Scale\%20Sports\%20Events\%20-\%20v2.pdf(Accessed: 20/04/2016).

[4]. Cody, K. and Jackson, S., (2014). The contested terrain of alcohol sponsorship of sport in New Zealand. International Review for the Sociology of Sport, Comparisons of pre- and post-games. Tourism Management, 27(1), 86-96.

[5]. Crompton, J.L., (1993). Sponsorship of sport by tobacco and alcohol companies: a review of the issues. Journal of Sport \& Social Issues, 17(2), pp.148-167.

[6]. Deccio, C. and Baloglu, S., (2002). Non host community resident reactions to the 2002 Winter Olympics: The spillover impacts. Journal of Travel Research, 41(1), pp.46-56.

[7]. FISA (2012) Environment Sustainability policy and headlines. Available http://www.worldrowing.com/mm//Document/features/Featuressection/11/84/31/FISA_emag19_December2011_Neutral.pdf (Accessed: 20/04/2016).

[8]. FISA (2013) BMW partner with world rowing for clean water. Available at: http://www.worldrowing.com/news/bmw-partnerswith-world-rowing-for-clean-water (Accessed: 20/04/2016).

[9]. Fredline, E. (2004). Host community reactions to motorsports events: the perception of impact on quality of life. In B. Ritchie \& D. Adair (Eds.), Sport Tourism: Interrelationships, Impacts and Issues, pp. 155-173. Clevedon: Channel View Publications.

[10]. G.J. Syme, B.J. Shaw, D.M. Fenton \& W.S. Mueller (Eds.), The Planning and Evaluation of Hallmark Events, pp. 3-40.

[11]. Great London Authority (2012). The environment sustainability of the London 2012 Olympic game and para Olympic game. Available at: https://www.london.gov.uk/sites/default/files/gla_migrate_files_destination/2012-sustainable-olympics.pdf(Accessed: 20/04/2016).

[12]. Hall, C.M., (1989). The definition and analysis of hallmark tourist events.GeoJournal, 19(3), pp.263-268.

[13]. Hiller, H.H., (1998). Assessing the impact of mega-events: a linkage model.Current issues in tourism, 1(1), pp.47-57.

[14]. INEI, (2014). Una Mirada a Aima Available at:https://www.inei.gob.pe/media/MenuRecursivo/publicaciones_digitales/Est/Lib1168/libro.pdf(Accessed: 20/04/2016).

[15]. IOC. (2016). The International Olympic Committee (IOC) today launched its global promotional campaign to communicate the Olympic Movement's vision of building a better world through sport. Available at:http://www.olympic.org/news/-together-we-canchange-the-world-ioc-launches-global-promotional-campaign/249065(Accessed: 20/04/2016).

[16]. Jenkins, H (2012) .The environment Impact of Sport- The case of football. Availble at: http://www.cardiff.ac.uk/cplan/sites/default/files/CCS-EnvImpactsSport-Football.pdf(Accessed: 20/04/2016).

[17]. Kim, H.J., Gursoy, D. and Lee, S.B., (2006). The impact of the 2002 World Cup on South Korea: comparisons of pre-and postgames. Tourism Management, 27(1), pp.86-96.

[18]. Kim, S., \& Petrick, J. (2005). Residents' perceptions on impacts of the FIFA2002World Cup: the caseof Seoul as a host city. Tourism Management, 26, 25-38.

[19]. Lee, M.S., Sandler, D.M. and Shani, D. (1997). Attitudinal constructs towards sponsorship: Scale development using three global sporting events.International Marketing Review, 14(3), pp.159-169. 
[20]. Liz Ellen. (2010). Protecting Sponsors at the London 2012 Olympics. Available at: http://www.mishcon.com/assets/managed/docs/downloads/doc_2413/Protecting_Sponsors_at_the_London_2012_Olympics_doc_(2 ).pdf (Accessed: 20/04/2016).

[21]. London organising committee for the Olympic Games (2012) Zero waste game vision. Available at: http://www.wrap.org.uk/sites/files/wrap/FULL\%20EPOW\%20presentationJB.pdf(Accessed: 20/04/2016).

[22]. Magdalinski, T. and Nauright, J. (2004) Commercializationof the modern Olympic Games,in T. Slack (ed.), The Commercialization of Sport, London, Routledge, pp. 185-204.

[23]. McDaniel, S.R., (1999). An investigation of match-up effects in sport sponsorship advertising: The implications of consumer advertising schemas.Psychology \& Marketing, 16(2), pp.163-184.

[24]. Metropolitan Police. (2015). Crime Figures (London) Available at: http://www.met.police.uk/crimefigures/(Accessed: 20/04/2016).

[25]. Mihalik, B.J., \& Cummings, P. (1995). Host perceptions of the 1996 Atlanta Olympics: support, attendance, benefits and liabilities. Travel and Tourism Research Association 26th Annual Proceedings. 397-400.

[26]. Misener, L. and Mason, D.S., (2006). Creating community networks: Can sporting events offer meaningful sources of social capital? Managing Leisure, 11(1), pp.39-56.

[27]. Philippe Bovy. (2010) Beijing 2008 Olympic Games success: massive public transport developments and major road traffic reduction. Available at: http://www.mobility-bovy.ch/resources/13.UITP_Beijing-EN.09.pdf (Accessed: 20/04/2016).

[28]. Preuss, H., (2007). The conceptualisation and measurement of mega sport event legacies. Journal of sport \& tourism, 12(3-4), pp. 207-228

[29]. Ritchie, B.W., Shipway, R. and Cleeve, B., (2009). Resident perceptions of mega-sporting events: A non-host city perspective of the 2012 London Olympic Games. Journal of Sport \& Tourism, 14(2-3), pp.143-167.

[30]. Ritchie, J.R.B., \& Aitken, C.E. (1985). OLYMPULSE II-Evolving resident attitudes towards the 1988 Olympic Winter Games. Journal of Travel Research, 23(3), 28-33.

[31]. Roche, M. (1994). Mega-events and urban policy. Annals of Tourism Research, 21(1), 1-19.

[32]. Seguin, B and Bodet, G. (2015) 'The Sponsors' perspective', in parent, M and Chappelet (eds.) Routledge Handbook of Sport Event Management. London: Roudledge.

[33]. Sport Accord (2015). World combat Games. Available at: http://www.sportaccord.com/media/news/world-combatgames/sportaccord-world-combat-games-2017-to-be-held-in-peru/(Accessed: 20/04/2016).

[34]. Sport England (2015) The benefits of sport. Available at: https://www.sportengland.org/research/benefits-of-sport/(Accessed: 20/04/2016)

[35]. Sport New Zealand (2012) sport sponsorship securing and retaining commercial partners. Available at: http://www.sportnz.org.nz/assets/uploads/attachments/managing-sport/strong-organisations/sport-sponsorship-securing-andretaining-commercial-partners.pdf (Accessed: 20/04/2016)

[36]. Stokvis, R., (2000). Globalization, commercialization and individualization: Conflicts and changes in elite athletics. Culture, Sport Society, 3(1), pp.22-34.

[37]. Sydney organising committee for the Olympic game (2003) championing the environment, Sydney 2000. Availble at: https://www.powerhousemuseum.com/sydney2000games/files/modules/18414933-2178-416A-

AEDC90C6FA84D051/Green_Games_case_study.pdf(Accessed: 20/04/2016).

[38]. Tosun, C. (2002). Host perceptions of impacts: a comparative tourism study. Annals of Tourism Research, 29(1), 231-253.

[39]. United national Environmental programme. (2009). Independent environmental assessment Beijing 2008 Olympic game. Availble at: http://www.unep.org/pdf/BEIJING_REPORT_COMPLETE.pdf(Accessed: 20/04/2016).

[40]. United National water (2014) united nation world water assessment program. Availble at: http://www.unesco.org/new/en/naturalsciences/environment/water/wwap/(Accessed: 20/04/2016)

[41]. Waitt, G. (2003). Social impacts of the Sydney Olympics. Annals of Tourism Research, 30(1), 194-215.

[42]. Water and resource Action Programme. (2012). London 2012 Legacy transfer report event waste management. Availble at: http://www.wrap.org.uk/sites/files/wrap/WRAP\%20London\%202012\%20Legacy\%20Transfer\%20Report\%20\%20-\%20Reuse \%20in\%20Events.pdf(Accessed: 20/04/2016).

[43]. WWF (2015). What are climate change and global warming? Available at: http://www.wwf.org.uk/what_we_do/tackling_climate_change/(Accessed: 20/04/2016). 